\title{
İki Parametreli Madde Tepki Kuramı Modelinde Parametre Değişmezliğinin İncelenmesi
}

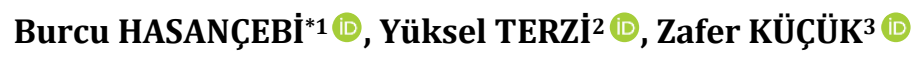 \\ 1,3Karadeniz Teknik Üniversitesi, Fen Fakültesi, İstatistik ve Bilgisayar Bilimleri Bölümü, 61080, Trabzon, \\ Türkiye \\ ${ }^{2}$ Ondokuz Mayıs Üniversitesi, Fen Edebiyat Fakültesi, İstatistik Bölümü, 55270, Samsun, Türkiye
}

(Alınıș / Received: 27.02.2020, Kabul / Accepted: 04.06.2020, Online Yayınlanma / Published Online: 20.08.2020)

\section{Anahtar Kelimeler Ölçme, \\ Madde tepki kuramı, İki parametreli model, Kruskal-Wallis Testi}

Özet: Ölçme teorisi incelendiğinde, temel olarak iki kurama rastlamak mümkündür. Bunlardan ilki Klasik Test Kuramı, diğeri ise Madde Tepki Kuramıdır. Madde Tepki Kuramını Klasik Test Kuramından ayıran birçok özellik mevcuttur. Bunlardan biri de parametre değişmezliği özelliğidir. Literatür incelendiğinde değişmezlik özelliğinin hala tartışma konusu olduğu görülmektedir. Bu bilgilerden hareketle bu çalışmada, Karadeniz Teknik Üniversitesi İstatistik ve Bilgisayar Bilimleri Bölümü Nesneye Yönelik Programlama dersinin final sınavı verileri incelenmiştir. Sınav 23 maddeden oluşmaktadır ve dersi alan tüm öğrencilere uygulanmıştır. Analizlere başlamadan önce, veri tarafından en çok desteklenen modelin İki Parametreli Madde Tepki Kuramı Modeli olduğu belirlenmiştir. Madde parametrelerinin değişmezlik özelliğini incelerken, katılımcllar cinsiyet ve dersi alış sayılarına göre alt bölümlere ayrılmıştır. Kişi parametreleri için ise maddeler, güçlük ve ayırt edicilik indekslerine göre ayrılmıştır. Her bir alt test için gerçek veriye benzer karakterde tepki vektörü simülasyon ile elde edilmiştir. Böylelikle, mevcut olan az miktardaki gerçek veri arttırılarak daha doğru sonuçlar elde etmek amaçlanmıştır. Analizden elde edilen sonuçlara göre madde ve kişi parametrelerinin tahminlerinin parametre değişmezliği ilkesine uygun olup olmadığı yorumlanmıştır.

\section{Investigation of Parameter Invariance in Two-Parameter Item Response Theory Model}

\section{Keywords}

Measurement,

Item response theory,

Two-Parameters model,

Kruskal-Wallis Test

\begin{abstract}
When the measurement theory is examined, it is possible to come across two theories. The first of these is Classical Test Theory and the other is Item Response Theory. There are many features that distinguish Item Response Theory from Classical Test Theory. One of these is the parameter invariance feature. When the literature is examined, it is seen that the invariance feature is still the subject of debate. Based on this information, in this study, the final exam data of Karadeniz Technical University Statistics and Computer Science Department Object Oriented Programming course were examined. The exam consists of 23 items and was applied to all students who took the course. Before starting the analyzes, it was determined that the model supported by the data was the Two Parameter Item Response Theory Model. When examining the invariance property of the item parameters, the participants were subdivided according to gender and the number of times they took the course. For the person parameters, the items were divided according to difficulty and discrimination indexes. The response vector for each subtest was obtained by simulation, with a character similar to the real data. According to the results obtained, it is interpreted whether the parameter invariance feature is provided or not.
\end{abstract}




\section{Giriş}

Ölçme teorisinin tarihine bakıldığında, ilk olarak Klasik Test Kuramı (KTK)'nın etkilerine rastlanmaktadır. KTK'da madde istatistikleri, ölçeğin uygulandığı gruba göre farklılık göstermektedir. Aynı maddelerin ilgili istatistikleri farklı özellikteki gruplara uygulandığında farklı sonuçlar vermektedir. $\mathrm{Bu}$ durumun tam aksine, Madde Tepki Kuramında (MTK), elde edilen madde istatistikleri grupların özelliklerinden bağımsızdır. İndeksler, ölçek hangi gruba uygulanırsa uygulansın değişmemektedir. Benzer şekilde, ölçeği alan kişilerin yetenek parametreleri de madde parametrelerinden bağımsız olarak elde edilir $[1,2,3]$. Yetenek ve madde parametreleri için söz konusu değişmezlik ilkesi ancak MTK varsayımlarının sağlanması ile mümkündür.

MTK'nın kullanılabilmesi için sağlanması gereken varsayımlar; tek boyutluluk, yerel bağımsızlık ve normallik varsayımlarıdır. Tek boyutluluk ölçeğin tek bir örtük özelliği ölçtüğü anlamına gelir. Tek boyutluluğun sağlanması için ölçekte baskın tek bir faktör yapısının gözlemlenmesi beklenir. Yerel bağımsızlık varsayımı, maddelere verilen tepkilerin istatistiksel olarak birbirinden bağımsız olması anlamına gelir. Yapılan tek boyutluluk testinin sonuçlarına göre, tek boyutluluk kriteri 0.9964 bulunmuştur. Yapının tek boyutlu olduğunu söyleyebilmek için tek boyutluluk kriterinin 1'e yakın çıkması gerekmektedir [4]. Tek boyutluluk varsayımının sağlanması halinde yerel bağımsızlık varsayımının da sağlandığı ortaya konulmuştur [3, 57]. Son varsayım normallik varsayımıdır. Normallik, KTK ile ortak tek varsayım olup ölçülen özelliğin normal dağılmasına dayanır. Ancak, MTK ile ölçme yapılırken artık lojistik regresyon modelleri kullanıldığından bu varsayım ortadan kalkmıştır.

Değişmezlik özelliği günümüzde tartışma konusu olmaya devam etmektedir. Bazı çalışmalarda değişmezlik sağlanırken bazısında belirli parametreler için sağlanmıştır. Bazı çalışmalarda ise bu ilke sağlanamamıștır. Doğan ve Kılıç, 3 parametreli model (3PL) ile yapılan çalışmalarında yetenek parametresinin değişmezlik ilkesini sağladığını ortaya koymuşlardır. Bunun yanında çalışmada madde parametreleri için yapılan analiz sonucunda, ayırıcllık ve şans parametresine göre güçlük parametresinin değişmezliği daha iyi sağladığı sonucuna varılmıştır [8]. Sünbül ve Erkuş, değişmezlik ilkesinin farklı örnek büyüklüklerinden ne derecede etkilendiğini araştırmış, $a$ ve $b$ parametrelerinin değişmezlik özelliğinin büyük ölçüde sağladığı sonucuna ulaşılmıştır [9]. Reyhanlıoğlu Keçeoğlu, farklı boyut ve örnek büyüklüklerinde değişmezlik ilkesi incelenmiş, yapının tek boyutlu ya da çok boyutlu olmasıyla örnek büyüklüklerinin farklı olması durumlarında değişmezlik ilkesinin etkilendiğini ortaya koymuştur
[10]. Acar ve Kelecioğlu, Genelleştirilmiş Aşamalı Doğrusal Model (GADM) ve Rasch modelden tahmin edilmiş kişi ve madde parametrelerinin değişmezlik özelliğini incelemişler ve iki modelde de madde parametreleri yüksek düzeyde değişmez iken, yetenek parametresi için değişmezliğin GADM ile tam olarak sağlandığını öne sürmüşlerdir [11]. Kelkar vd., Tıp Fakültesi sınavları için sadece güçlük parametresi içeren 1 parametreli (1PL) model, güçlük ve ayırt edicilik parametrelerini içeren 2 parametreli (2PL) model ve güçlük ayırt edicilik ile şans parametresi içeren 3 parametreli (3PL) MTK modellerinde değişmezlik ilkesini incelemişlerdir. Madde parametreleri için cinsiyet, etnik grup ve dile göre alt gruplar oluşturmuş, yetenek parametresinin değişmezliği için ise güçlüğe göre alt testlere ayrılmıştır. 1PL'den elde edilen tahminler en küçük standart hataya sahipken, 2PL ve 3PL modeller arasındaki fark oldukça küçük bulunmuştur. Tüm modeller için değişmezlik sağlanmasına rağmen en güçlü değişmezlik 1PL modelde sağlanmıştır [12]. Custer vd., 1PL ve 3PL modelde değişmezlik ilkesini incelemişlerdir. Veriden en fazla desteği alan modelin 3PL olmasına rağmen değișmezlik ilkesini düşük, orta ve yüksek yetenek gruplarının hepsinde ve madde parametrelerinde 1PL model sağlamıștır [13]. Adedoyin, yetenek parametresinin değişmezliğini KTK ve MTK anlamında karşılaştırmıştır. KTK ile tahmin edilen kişi parametrelerinde değişmezlik gözlenmezken, MTK ile yapılan tahminlerde değişmezlik özelliği saptanmıştır [14]. Adedoyin vd., madde parametrelerinin değişmezliği MTK ve KTK'ya dayalı araștırmışlardır. KTK ile yapılan analizler sonucu güçlük parametresinin örnekten örneğe farklılık gösterdiğini, MTK ile yapılan tahminlerin ise farklı örneklerde değişmez olduğunu ortaya koymuşlardır [15].

$\mathrm{Bu}$ çalışmada, Nesneye Yönelik Programlama dersinin final sınavı verileri üzerinde değişmezlik çalışması yapılmıştır. Analizler hem madde hem kişi parametreleri için yapılmış, her durumda veri çeşitli özelliklere göre alt testlere bölünmüştür. Ölçek, 81 kişiye uygulanmıştır. Ancak, elde edilen alt testlerde çok az sayıda örnek bulunması sebebiyle her alt test için, gerçek veriye benzer karakterde cevap verisi simülasyon ile elde edilmiştir. Böylelikle, her bir alt test için 1000'er kişilik tepki vektörü oluşturulmuştur. Literatürde, model veri uyumunun en yüksek olduğu modeller genelde 3PL model olarak seçilmiş ancak, değişmezliğin en iyi 1PL modelle sağlandığ görülmüștür. Çalışmada, veriden en yüksek desteği alan model 2PL model olarak belirlenmiş ve 2PL modelde değişmezlik ilkesi incelenmiştir.

\section{Materyal ve Metot}

Bu çalışmada, Karadeniz Teknik Üniversitesi İstatistik ve Bilgisayar Bilimleri Bölümü 2018-2019 Eğitim Öğretim yılı Bahar döneminde verilen Nesneye 
Yönelik Programlama dersinin final sınavı analiz edilmiştir. Ölçek, 23 maddeden oluşmaktadır. Her bir madde 4 seçeneklidir. Test, dersin kazanımları baz alınarak hazırlanmıștır. Ölçek, dersi alan 81 öğrenciye uygulanmıș ve öğrencilerden elde edilen veriler 0-1 şeklinde ikili sisteme dönüştürülmüştür. Yetenek ve madde parametrelerinin her biri için değişmezlik ilkesi incelenmiştir. Bunu yaparken, herhangi bir cinsiyet grubunun veya dersi bir ya da birden fazla kez almış olmanın parametre tahmininde etkili olup olmadığını araștırabilmek için madde parametrelerinin değişmezliği incelenirken öğrenciler, cinsiyetleri ve dersi alış sayılarına göre gruplandırılmıştır. Benzer şekilde, yetenek parametresinin değişmezliği için ise ölçek, maddelerin güçlük ve ayırt edicilik düzeylerine göre alt testlere bölünmüștür. Böylelikle, benzer ya da farklı maddelerin yetenek parametresinin tahminini değiştirip değiştirmeyeceği incelenmiştir. Mevcut tüm alt testler için gerçek veriye benzer karakterde yapılan simülasyon çalışması ile tüm alt testlerde örnek sayısı 1000'e çıkarılmıştır.

Tablo 1. Grup ve test için betimsel istatistikler

\begin{tabular}{cccc}
\hline $\begin{array}{c}\text { Örnek } \\
\text { Sayısı }\end{array}$ & $\begin{array}{c}\text { Madde } \\
\text { Sayısı }\end{array}$ & $\begin{array}{c}\text { Dizi } \\
\text { Genișliği }\end{array}$ & $\begin{array}{c}\text { Ortalama } \\
\text { Güçlük }\end{array}$ \\
\hline 8000 & 23 & 22 & 0.05 \\
\hline
\end{tabular}

Tablo 1'de grup ve test için bazı betimsel istatistikler verilmiştir. Ölçek 81 kişiye uygulanmış ancak yapılan simülasyon çalışması ile örnek sayısı 8000'e çıkarılmıştır. Testin ortalama güçlüğü 0.05 olarak hesaplanmıştır. Testin ortalama güçlüğünün $0.5^{\prime}$ den küçük olması, ölçekteki maddelerin öğrenciye zor geldiği ya da düşük düzeyli öğrencilerin çoğunlukta olduğu biçiminde yorumlanabilir. Ölçek 23 maddeden oluşmaktadır ve ranj aralığı 22 olarak hesaplanmıştır.

Ölçme teorisinde kullanılan bir ölçeğin geçerliliğinin ve güvenilirliğinin düşük olması da analizlerden elde edilecek kestirimlerin objektifliğine, hassaslığına ve doğruluğuna șüphe düșürmektedir. Buradan doğan ihtiyaçla, mevcut veriye güvenilirlik analizi yapılmış ve Cronbach alfa katsayıları her bir madde için 0.92 civarında bulunmuştur. Böylelikle, geliştirilen ölçeğin yüksek düzeyde güvenilir olduğunu söylemek mümkündür.

Analizlerden önce modele karar vermek en önemli adımdır. Verilerden en yüksek desteği alan modeli seçmek yapılacak kestirimlerin doğruluğu açısından oldukça önemli bir rol oynar. Bu sebeple, 1PL, 2PL ve 3PL modellerin çeşitli uyum kriterleri ile karşılaştırmaları yapılmıştır. Elde edilen sonuçlara göre, AIC, BIC ve DIC değerlerinin en küçük, log likelihood değerinin ise en büyük olduğu model olan 2PL modelin en uygun model olduğu Tablo 2'de verilmiştir. 2PL modelde madde parametresi olarak güçlük parametresinin yanında ayırt edicilik parametresi de mevcuttur. Kiși parametresi olarak yetenek parametresi her modelde bulunmaktadır.

$$
P_{i}(\theta)=\frac{\exp \left[a_{i}\left(\theta-b_{i}\right)\right]}{1+\exp \left[a_{i}\left(\theta-b_{i}\right)\right]}
$$

Eşitlik 1. ile 2PL model matematiksel olarak ifade edilmektedir [16]. Burada, $i$, madde sayısı olmak üzere; $a_{i}, i$. maddenin ayırt edicilik parametresidir. Ayırt edicilik parametresi, maddenin ölçülmek istenen özelliğe sahip olan öğrenci ile olmayan öğrenciyi birbirinden ayırabilme becerisidir. $b_{i}, i$. maddenin güçlük indeksidir. $\mathrm{Bu}$ indeks ile, maddenin zorluk derecesi hakkında kolay, orta ya da zor biçiminde yorum yapılmasını sağlar. Kişi parametresi $\theta$ ise ögrencilerin yetenek düzeylerini gösteren parametredir.

Kişilere uygulanan ölçeklerin ana amacı ilgili kişilerin ölçülmek istenen örtük özelliklere sahip olup olmadıklarını, sahipseler ne kadar sahip olduklarını belirlemektir. Böylece, kișilerin yetenek ölçeği üzerindeki konumları belirlenir. Yetenek parametrelerinin tahmini için madde parametrelerinin bilinmesi gerekmektedir. Kişilerden elde edilen cevap vektörü ve madde parametreleri yardımıyla kiși yeteneklerinin tahminleri yapılır [8]. Yetenek parametresinin kestirimi yapılırken öncelikle ham puanlar mı tüm cevapların örüntüsü mü kullanılacak buna karar verilmelidir. Örüntü yönteminde, aynı sayıda fakat farklı güçlük düzeylerindeki maddeleri doğru cevaplayanlar farklı yetenek tahminine sahip olabilmektedirler. Toplam puan ile toplam doğru cevap sayıları kullanılarak yetenek kestiriminde bulunulmaktadır. Bu yöntemde aynı doğru cevap puanına sahip öğrenciler hangi maddeleri doğru yanitlarsa yanitlasınlar her zaman aynı yetenek düzeyine sahip olmaktadırlar. $\mathrm{Bu}$ nedenle, toplam puan, örüntü puanlamaya göre daha fazla ölçme hatası içerir [17].

Analizlere başlamadan önce tüm tepki vektöründen madde ve kişi parametreleri kestirilmiştir. Parametre değişmezliği özelliğini incelemek için farklı özelliklere sahip madde ve kişileri bir araya toplayarak alt testler ve alt gruplar oluşturulmuştur. Tüm bu ayrıștırma önceden kestirilmiş parametrelere dayanarak yapılmıştır. Model 2PL olarak seçildiğinden modelde güçlük ve ayırıcılık olarak 2 madde parametresi mevcuttur. Madde parametreleri için değișmezlik incelenirken kișilerin cinsiyetleri ve dersi kaçıncı alışları (ilk defa alanlar ve alttan alanlar) olduğuna göre alt gruplara ayrıştırma yapılmıştır. Kişi parametresi (yetenek parametresi) için de güçlükleri 
Tablo 2. Model veri uyumu

\begin{tabular}{ccccc}
\hline Model & logLikelihood & AIC & BIC & DIC \\
\hline 1PL/Rasch & -907.5408 & 1863.082 & 1920.548 & 1815.082 \\
\hline 2PL & -831.5121 & 1757.024 & 1869.563 & 1663.024 \\
\hline 3PL & -853.9027 & 1799.805 & 1909.950 & 1707.805 \\
\hline
\end{tabular}

düşük ve yüksek ile ayırıcılıkları düşük ve yüksek olmak üzere ölçek alt testlere bölünmüştür.

Parametrelerin özelliklerine göre tüm alt gruplar ve alt testlerin oluşturulma adımının ardından elde edilen farklı özellikteki grupların değişmezlik özelliğini sağlayıp sağlamadığı incelenmiștir. Örneğin, güçlük parametresinin değişmezliği incelenirken mevcut maddelerin parametreleri bölünmüş her alt grupta aynı mıdır? Yoksa örnekten örneğe istatistiksel olarak anlamlı farklılıklar göstermekte midir? $\mathrm{Bu}$ soruların yanıtı için kestirilen parametrelerin gruptan gruba değişip değișmediği incelenmelidir.

Mevcut veriden elde edilen her bir alt test ve alt gruba normallik testi yapılmıștır. Verinin normal dağılıp dağılmadığının incelenmesi için Shapiro-Wilk Testi kullanılmıştır. Shapiro-Wilk Testinin sonuçlarına göre güçlük, ayırt edicilik ve yetenek parametrelerinin değişmezliğinin analizi için elde edilmiş alt gruplardan kestirilen parametrelerin normal dağılmadığı sonucuna ulaşılmıştır. Bu durumda, alt gruplar arasında fark var mı sorusunun cevabını aramak için parametrik olmayan testlerden Kruskal-Wallis Testi uygulanmıș, elde edilen sonuçlara göre değişmezlik özelliği hakkında yorumlar yapılmıștır.

\section{Bulgular}

$\mathrm{Bu}$ çalışmadaki ana amaç, her bir alt grup için kestirilen parametrelerin gruptan gruba değişip değişmediğini ölçmektir. Bu amaca yönelik yapılan ilk çalışma belirlenmiş grupların normal dağılıp dağılmadığını ölçmektir. Bunun için Shapiro-Wilk Testi her bir gruba uygulanmıştır.

Analizlere başlamadan önce uygulanan ölçek yapısının tek boyutlu olduğu tek boyutluluk kriterinin 0,9964 bulunmasıyla belirlenmiş ve modelin Tablo 2'deki uyum kriterlerinden hareketle 2PL modele uyumlu olduğu tespit edilmiştir. Analizler yapılırken bu bilgiler baz alınarak yapılmıştır. Tüm analizler $\mathrm{R}$ yazılımı ile gerçekleştirilmiştir.

Tablo 3. Güçlük parametresi için Shapiro-Wilk Test sonuçları

\begin{tabular}{ccc}
\hline Alt gruplar & Test İstatistiği & $\mathbf{p}$ \\
\hline Klz & 0.7704 & 0.0001 \\
\hline Erkek & 0.9029 & 0.0291 \\
\hline İlk defa alanlar & 0.9529 & 0.3357 \\
\hline Alttan alanlar & 0.7574 & $8.591 \mathrm{e}-05$ \\
\hline
\end{tabular}

Tablo 3'de ilgili örneklerin normal dağılımdan geldiği yokluk hipotezini test eden ve anlamlılık düzeyi 0.05 olarak seçilmiș Shapiro-Wilk testinin sonuçları görülmektedir. Bu durumda, güçlük parametresi için elde edilen sonuçlardan sadece ilk defa alanlar grubunun normal dağılıma sahip olduğu görülmektedir. Geride kalan kız, erkek ve alttan alanlar grupları normal dağılımdan gelmemektedir. İlgili örneklerin normal dağılımdan farkı yoktur, yokluk hipotezinin testinde anlamlılık düzeyi 0.05 olarak belirlenmiştir ve Tablo 4'de verilen $p$ değerlerine bakıldığında, örnek içerisindeki tüm grupların normal dağılımdan gelmediğini görmek mümkündür.

Tablo 4. Ayırıcıllk parametresi için Shapiro-Wilk Test sonuçları

\begin{tabular}{ccc}
\hline Alt gruplar & Test İstatistiği & p \\
\hline Kız & 0.5607 & $3.441 \mathrm{e}-07$ \\
\hline Erkek & 0.4220 & $1.671 \mathrm{e}-08$ \\
\hline İlk defa alanlar & 0.49617 & $7.881 \mathrm{e}-08$ \\
\hline Alttan alanlar & 0.63435 & $2.199 \mathrm{e}-06$ \\
\hline
\end{tabular}

Tablo 5. Yetenek parametresi için Shapiro-Wilk Test sonuçları

\begin{tabular}{ccc}
\hline Alt gruplar & Test İstatistiği & p \\
\hline Güçlükler düşük & 0.9174 & $6.24 \mathrm{e}-23$ \\
\hline Güçlükler yüksek & 0.9002 & $5.46 \mathrm{e}-25$ \\
\hline Ayırıcılık düşük & 0.9031 & $1.16 \mathrm{e}-24$ \\
\hline Ayırıcılık yüksek & 0.8330 & $4.51 \mathrm{e}-31$ \\
\hline
\end{tabular}

Tablo 5'de örneklerin normal dağılımdan gelip gelmediğini test eden Shapiro-Wilk testinin test istatistikleri ve p değerleri görülmektedir. Elde edilen sonuçlara göre hiçbir grup normal dağılımdan gelmemektedir.

Yapılan normallik testlerinden elde edilen bilgilere göre çoklu gruplar arasında istatistiksel olarak anlamlı bir fark bulunup bulunmadığının testi için parametrik olmayan testlere başvurulmalıdır. Parametrik testlerden ANOVA'nın karșılığ olan Kruskal-Wallis testi bu veriler için uygun test olacaktır.

Tablo 6. Güçlük parametresi için Kruskal-Wallis Testi sonuçları

\begin{tabular}{ccc}
\hline \multicolumn{3}{c}{ Kruskal-Wallis rank sum test } \\
\hline$\chi^{2}$ & Serbestlik derecesi & $\mathbf{p}$ \\
\hline 2.8368 & 3 & 0.4175 \\
\hline
\end{tabular}

Tablo 6 ile güçlük parametresinin değişmezliği incelenmiştir. Değişmezlik incelenirken gruplar arasında fark olup olmadığına Kruskal-Wallis testi ile bakılmıștır. Test, kestirilen parametrelerin gruptan gruba değişmediğini ifade eden yokluk hipotezini test eder ve anlamlılık düzeyi 0.05 olarak belirlenmiștir. Tablo 6'da gösterilen p değerine göre yokluk hipotezi kabul edilir. Bu, gruplar arasında kestirilen güçlük parametrelerinin arasında istatistiksel olarak anlamlı 
bir fark yok olarak yorumlanır. Yani, güçlük parametresi için değişmezlik ilkesi sağlanmıştır.

Tablo 7. Ayırıcılık parametresi için Kruskal-Wallis Testi sonuçları

\begin{tabular}{ccc}
\hline \multicolumn{3}{c}{ Kruskal-Wallis rank sum test } \\
\hline$\chi^{2}$ & Serbestlik derecesi & $\mathbf{p}$ \\
\hline 51.517 & 3 & $3.796 \mathrm{e}-11$ \\
\hline
\end{tabular}

Tablo 7'de ayırt edicilik parametresinin belirlenmiş alt gruplar için değişmezlik ilkesini sağlayıp sağlamadığına ilişkin test sonuçları görülmektedir. Anlamlılık düzeyi 0.05 olmak üzere; p değerine bakıldığında ayırıcılık indeksinin değişmezlik özelliğini sağlamadığı görülmektedir. Bu durumda; hangi alt grupta farklılık olduğunun belirlenmesi için Kruskal-Wallis testi için çoklu karşılaştırmalar Dunn Testi ile yapılmıştır.

Tablo 8. Ayırıcılık parametresi için Dunn Testi sonuçları

\begin{tabular}{|c|c|c|c|c|}
\hline \multicolumn{2}{|c|}{$\begin{array}{c}\text { Satır ortalaması / } \\
\text { Sütun ortalaması }\end{array}$} & $\begin{array}{c}\text { Alttan } \\
\text { alanlar }\end{array}$ & Erkek & $\mathrm{Klz}$ \\
\hline Erkek & Test ist. & -5.6432 & & \\
& $\mathrm{p}$ & $0.0000^{*}$ & & \\
\hline $\mathrm{K} ı \mathrm{z}$ & Test ist. & -5.7150 & -0.0717 & \\
& $\mathrm{P}$ & $0.0000^{*}$ & 1.0000 & \\
\hline İlk defa & Test ist. & -6.1677 & -0.5245 & -0.4527 \\
alanlar & $\mathrm{p}$ & $0.0000^{*}$ & 1.0000 & 1.0000 \\
\hline
\end{tabular}

Tablo 8'de ayırıcılık parametresi için KruskalWallis'in çoklu karşılaştırma testi yapılmıştır. Elde edilen sonuçlara göre, erkek ve alttan alanlar grubu, kız ve alttan alanlar grubu ve ilk defa alanlar ve alttan alanlar grubu arasında istatistiksel olarak anlamlı fark bulunmuştur. Bu durumda, bu alt gruplar için kestirilen ayırıcılık parametresinin değişmezlik ilkesini sağlamadığı söylenebilir. Yani, bu gruplarda örnekten örneğe kestirilen ayırıcılık değerleri farklı olacaktır.

Tablo 9. Yetenek parametresi için Kruskal-Wallis Testi sonuçları

\begin{tabular}{ccc}
\hline \multicolumn{3}{c}{ Kruskal-Wallis rank sum test } \\
\hline$\chi^{\mathbf{2}}$ & Serbestlik derecesi & $\mathbf{p}$ \\
\hline 242.29 & 3 & $2.2 \mathrm{e}-16$ \\
\hline
\end{tabular}

Tablo 9'da yetenek parametresi için yapılmış Kruskal-Wallis testinin sonuçları görülmektedir. Belirlenmiş alt gruplar arasında istatistiksel olarak anlamlı bir fark yoktur yokluk hipotezini test eden testin $\mathrm{p}$ değerine göre en az bir grupta farklılık olduğu sonucuna varılmıştır. Hangi gruplar arasında farklılık olduğunu belirlemek için çoklu karşılaştırma testlerinden Dunn Testi kullanılmıștır.

Tablo 10. Yetenek parametresi için Dunn Testi sonuçları

\begin{tabular}{|c|c|c|c|c|}
\hline \multicolumn{2}{|c|}{ Satır Ortalaması / } & $\begin{array}{c}\text { Ayırıcılı̆̆ } \\
\text { Sütun Ortalaması }\end{array}$ & $\begin{array}{c}\text { Güçlüğü } \\
\text { düșük }\end{array}$ & $\begin{array}{c}\text { Güçlüğü } \\
\text { yüksek }\end{array}$ \\
\hline Güçlüğü & $\begin{array}{c}\text { Test ist. } \\
\text { düşük }\end{array}$ & -11.3187 & & \\
$0.0000^{*}$ & & \\
\hline Güçlüğü & Test ist. & -10.7772 & 0.5414 & \\
yüksek & $\mathrm{P}$ & $0.0000^{*}$ & 1.0000 & \\
\hline Ayırııılığı & Test ist. & -14.6340 & -3.3153 & -3.8568 \\
düșük & $\mathrm{p}$ & $0.0000^{*}$ & $0.0027^{*}$ & $0.0000^{*}$ \\
\hline
\end{tabular}

Kruskal-Wallis Testinde bazı gruplarda istatistiksel olarak anlamlı farklılık gözlemlendiği Tablo 9 ile belirlenmiştir. Tablo 10'da ise bu anlamlı farklılığın hangi gruplar arasında olduğunu belirlemek için Dunn Testi yapılmış ve sonuçları gösterilmiştir. Tablo 10'a göre, ayırıcılığı yüksek ile güçlüğü düşük grup, güçlügü yüksek grup ve ayırıcılığı yüksek grup ayrıca da güçlüğü düşük grupla ayırıcılığı düşük grup arasında yapılmış kestirimlerde anlamlı farklılıklar gözlemlenmiștir. $\mathrm{Bu}$ durumda, belirlenmiş bu gruplardan elde edilen yetenek kestirimleri değişmezlik ilkesini sağlamayacaktır sonucuna ulaşılır.

\section{Tartışma ve Sonuç}

Bu çalışmada, Karadeniz Teknik Üniversitesi İstatistik ve Bilgisayar Bilimleri Bölümünde verilen Nesneye Yönelik Programlama dersinin final sınavı verileri kullanılmıştır. Değişmezlik ilkesinin incelenmesi için yetenek ve madde parametrelerine göre alt gruplar oluşturulmalı ve bu alt gruplardan elde edilen parametre kestirimlerinin değişmez olup olmadığı incelenmelidir. $\mathrm{Bu}$ sebeple, madde parametrelerinin değişmezliğinin incelenmesi için cinsiyet ile dersi ilk defa alanlar ve alttan alanlar şeklinde alt gruplar olușturulmuștur. Yetenek parametresinin değişmezliğinin incelenebilmesi için ise güçlüğü düşük, güçlüğü yüksek ve ayırıcılığı düşük ve ayırıcılığı yüksek olmak üzere alt testler oluşturulmuştur.

Nesneye Yönelik Programlama dersini alan toplamda 81 öğrenci mevcuttur ve alt gruplar oluşturulduğunda bu sayı daha da azalmaktadır. Bu sebeple, alt gruplara ve alt testlere ayrılmış veri üzerinden, gerçek veri karakterine benzer veri, simülasyon ile elde edilmiştir. Böylelikle her bir alt grupta gerçek veriye benzeyen 1000'er örnek elde edilmiştir. Yapılan tüm analizler $\mathrm{R}$ yazılımı ile yapılmıştır.

MTK modelleri ile çalışabilmek için birtakım varsayımların sağlanması gerekmektedir. Bunlardan ilki tek boyutluluk varsayımıdır. Bu sebeple veriye Tek Boyutluluk Testi uygulanmış tek boyutluluk kriteri 0.9964 olarak elde edilmiştir. Literatüre bakıldığında, tek boyutluluktan söz edebilmek için hesaplanan kriterin 1'e yakın olması gerektiği görülmektedir. Kriter 1'e ne kadar yakınsa yapının tek boyutlu olduğunun ispatı o kadar güçlüdür [4]. Diğer bir varsayım yerel bağımsızlık varsayımıdır. Bir yapının tek boyutluluk varsayımını sağladığı durumda, yerel bağımsızlık varsayımını da karşıladığını söylemek mümkündür [3, 5, 7]. Son varsayım normallik, kullanılan modellerin lojistik regresyon modelleri olması sebebiyle önemini yitirmiş bir varsayımdır.

Varsayımların sağlanmasıyla birlikte hangi MTK modeli ile çalışılacağı sorusu gündeme gelmektedir. 
Model-veri uyumunun maksimum olduğu modeli bulmak yapılacak analiz sonuçlarının doğruluğu için oldukça önemlidir. Aksi halde, yanlıș kestirimler yapılır ve bundan kaynaklanan yanlış yorumlar kaçınılmaz olur. $\mathrm{Bu}$ durumun önüne geçmek açısından çalışmada MTK modelleri çeşitli uyum kriterleri açısından karşılaştırılmış ve en uygun modelin 2PL model olduğu görülmüştür. Ardından, modelde mevcut olan güçlük, ayırıcılık ve yetenek parametrelerinin kestirimi yapılmıştır.

Kestirimleri yapılmış model parametrelerinin normalliği araştırılmış, parametrelere Shapiro-Wilks Testi uygulanmıştır. Test sonuçlarına göre, sadece güçlük parametresi için yapılan testte dersi ilk defa alanlar grubu normal dağılım göstermiş, diğer gruplarda normal dağılıma rastlanmamıştır. Hatta, ayırıcılık için yapılan testte ilk defa alanlar grubu da normal dağglım göstermemiștir. $\mathrm{Bu}$ durumda, gruplardan kestirilmiş madde ve kişi parametreleri arasında fark olup olmadı̆̆ının test edilebilmesi için Kruskal-Wallis Testi yapılmıștır. Kruskal-Wallis testi sonuçlarına göre, sadece güçlük parametresinin değişmezlik ilkesinin sağlandığı gözlemlenmiştir. Ayırıcılık ve yetenek parametreleri değişmezlik özelliğini sağlamamıştır. Bu durumda, ayırıcılık ve yetenek parametrelerinde istatistiksel olarak anlamlı farklılık içeren grupların hangisi olduğu sorusu akla gelmektedir. Kruskal-Wallis testinin çoklu karşılaștırma testi Dunn Testidir. Ayırıcılık ve yetenek parametreleri için Dunn Testi yapılmış ve sonuçlar sırasıyla Tablo 8 ve Tablo 10'da verilmiştir.

Literatür incelendiğinde, değişmezlik ilkesi ile ilgili farklı sonuçlar alınmış çalışmalar olduğu görülmektedir. 3PL modellerin veri uyumlarının en yüksek olduğu ancak değișmezliğin 1PL modeller ile en iyi sağlandığı ortaya konulmuştur [13]. Madde parametrelerinden güçlüğü en iyi sağlayan parametrenin ise güçlük parametresi olduğu belirlenmiştir. Bunun yanında yetenek parametresinin de değişmez olduğu gösterilmiștir [9]. MTK modelleri ile yapılan değişmezlik çalışmasında en güçlü değişmezliğin 1PL model ile sağlandığı sonucuna varılmıştır [12]. Güçlük parametresi için KTK ve MTK çerçevesinde değişmezliğin incelendiği çalışmada, KTK kapsamında kişi parametresi tahminleri, hiçbir alt testte değişmezlik göstermemiştir. Yine KTK çerçevesinde güçlük parametresinin değişmezliği için farklı alt gruplarda değişmezliğin sağlandığı sonucuna varılmıştır. MTK çerçevesinde yapılan tahminlerde ise, güçlük parametresi farklı alt gruplarda değişmez iken, farklı örnek boyutlarında değişmezliği sağlamadığı sonucu ortaya konulmuştur [15]. Yapılan literatür araştırmaları sonunda konuyla ilgili 2PL modelle yapılmış çalışmaların sayıca fazla olmadı ğ genelde 1PL model ve 3PL modeller ile çalışıldığı, bazı durumlarda iki modelin karşılaştırmasının yapıldığı göze çarpmaktadır. Ayrıca, bu çalıșma gerçek veriden hareketle simülasyon verisi üretmesi sebebiyle sadece simülasyon ile elde edilmiş veri ile yapılan çalışmalardan ve sadece gerçek veri ile yapılmış çalışmalardan ayrılmaktadır. Bu özellikleri ile yapılan çalışmada sadece güçlük parametresinin değişmezliği sağladığı sonucuna ulaşılmıştır.

\section{Kaynakça}

[1] Hambleton, R., Swaminathan, H. 1985. Item Response Theory: Principles and Applications. Springer Science\& Business Media, USA, 332s.

[2] Embretson, S.E., Reise, S.P. 2000. Item Response Theory for Psychologists. Psychology Press, Los Angeles, 384s.

[3] De Mars, C. 2010. Item Response Theory. Oxford University Press, New York, 130s.

[4] Drasgow, F., Lissak, R. I. 1983. Modified parallel analysis: A Procedure for Examining the Latent Dimensionality of Dichotomously Scored Item Responses. Journal of Applied Psychology, 68(3), 363-373.

[5] De Gruijter, DNM., van der Kamp, LJT. 2008. Statistical Test Theory for the Behavioral Sciences. Psychometrika, 73(4), 791-792.

[6] Recklase, M.D. 2009. Multidimensional Item Response Theory. Springer, New York, 339s.

[7] Güler, N. ed. 2016. Madde Tepki Kuramının Temelleri. Pegem Akademi, Ankara, 171s.

[8] Doğan, N., Kılıç, A.F. 2017. Madde Tepki Kuramı Yetenek ve Madde Parametreleri Kestirimlerinin Değişmezliğinin İncelenmesi. ss 297-314. Demirel, Ö., Dinçer, S., ed. 2017. Küreselleșen Dünyada Eğitim, Pegem Akademi, Ankara, 902s.

[9] Sünbül, Ö., Erkuş, A. 2013. Madde Parametrelerinin Değişmezliğinin Çeşitli Boyutluluk Özelliği Gösteren Yapılarda Madde Tepki Kuramına Göre İncelenmesi. Mersin Üniversitesi Eğitim Fakültesi Dergisi, 9(2), 378398.

[10] Reyhanlığlu Keceoğlu, C.. 2018. Parametrik ve Parametrik Olmayan Madde Tepki Kuramında Farklı Örneklem Büyüklüklerine ve Boyutluluklarına Göre Parametre Değişmezliğinin İncelenmesi. Hacettepe Üniversitesi, Eğitim Bilimleri Enstitüsü, Doktora Tezi, 111s, Ankara.

[11] Acar, T., Kelecioğlu, H. 2008. Genelleştirilmiş Așamalı Doğrusal Model ile Rasch Modelinin Parametre Değişmezliğinin Karşılaştırılması. I. Ulusal Eğitimde ve Psikolojide Ölçme ve Değerlendirme Kongresi, 14-16 Mayıs, Ankara, 181-193.

[12] Kelkar, V., Wightman, L.F., Luecht, R.M. 2000. Evaluation of the IRT Parameter Invariance Property for the MCAT. Annual Meeting of the 
National Council on Measurement in Education, 25-27 April, New Orleans.

[13] Custer, M., Sharairi, S., Yamazaki, K., Signatur, D., Swift, D., Frey, S. 2008. A Paradox Between IRT Invariance And Model-Data Fit When Utilizing the One-Parameter and Three-Parameter Models. Annual Meeting of the American Educational Research Association, 24-28 March, New York, 70-71.

[14] Adedoyin, 0.0. 2010. Investigating the Invariance of Person Parameter Estimates Based on Classical Test and Item Response Theories. International Journal of Education Science, 2(2), 107-113.

[15] Adedoyin, 0.0., Nenty, H.J., Chilasa, B. 2008. Investigating the Invariance of Item Difficulty Parameter Estimates Based on CTT and IRT. Educational Research and Review, 3(2), 83-93.

[16] Birnbaum, A. 1968. Some Latent Trait Models and Their Use in Inferring an Examinee's Ability. ss 379-398. Lord, F.M., Novick, M.R. ed. 1968.
Statistical theories of mental test score, AddisonWesley, USA, 460s.

[17] Orlando, M., Thissen, D. 2000. New Item Fit Indices for Dichotomous Item Response Theory Models. Applied Psychological Measurement, 24(1), 50-64. 